\title{
Preparation of Ammonia Dealuminated Metakaolinite and Its Adsorption against Bixin
}

\author{
Winda Rahmalia ${ }^{1}$, Jean-François Fabre ${ }^{2}$, Thamrin Usman ${ }^{1, *}$, and Zéphirin Mouloungui ${ }^{2,3}$ \\ ${ }^{1}$ Department of Chemistry, Faculty of Mathematics and Natural Sciences, Tanjungpura University, \\ Jl. Prof. Dr. H. Hadari Nawawi, Pontianak 78124, West Kalimantan, Indonesia \\ ${ }^{2}$ Université de Toulouse, INP-ENSIACET, Laboratoire de Chimie Agro-industrielle (LCA), \\ 4 Allée Emile Monso, 31030 Toulouse, France
}

${ }^{3}$ INRA, UMR 1010 CAI, F-31030 Toulouse, France

* Corresponding author:

tel: $+62-561-577963$

email: thamrin_usman@.untan.ac.id

Received: April 3, 2019

Accepted: August 30, 2019

DOI: $10.22146 /$ ijc. 44706

\begin{abstract}
This study aims to prepare dealuminated metakaolinite which has a high surface area by using $\mathrm{NH}_{4} \mathrm{OH}$ as an activator. The natural kaolinite sample was treated at $600{ }^{\circ} \mathrm{C}$ for $6 \mathrm{~h}$ in order to obtain metakaolinite. A dealuminated metakaolinite was then prepared by the repeated activation method using concentrated ammonia (5 $\left.\mathrm{M} \mathrm{NH}_{4} \mathrm{OH}\right)$ at room temperature. Depending on the nature of each type of material, natural kaolinite, $\mathrm{NH}_{4} \mathrm{OH}$ treated kaolinite, metakaolinite and $\mathrm{NH}_{4} \mathrm{OH}$ treated metakaolinite were characterized using X-ray diffraction (XRD), Fourier-transform infrared spectroscopy (FTIR), scanning electron microscopy-energy dispersive spectroscopy (SEM-EDS), and Brunauer-EmmettTeller $\left(B E T-N_{2}\right)$ measurements. XRD and FTIR results confirmed that structural transformation from kaolinite to metakaolinite had occurred. According to SEM-EDS data, the activation of metakaolinite by $\mathrm{NH}_{4} \mathrm{OH}$ allowed the dealumination of metakaolinite. The increase in the Si/Al ratio was almost twice as high as in kaolinite. BET- $\mathrm{N}_{2}$ analysis showed that the specific surface area and the total pore volume increased significantly after activation. Its adsorption properties were tested against bixin. Bixin adsorption on dealuminated metakaolinite followed pseudo-second order kinetic where $k_{2}=0.20 \mathrm{~g} / \mathrm{mg} \mathrm{min}$. The adsorption isotherm followed the Langmuir model where qm $=0.72 \mathrm{mg} / \mathrm{g}$.
\end{abstract}

Keywords: ammonia; adsorption; bixin; metakaolinite

\section{- INTRODUCTION}

Kaolinite $\left[\mathrm{Al}_{2} \mathrm{Si}_{2} \mathrm{O}_{3}(\mathrm{OH})_{4}\right]$ is a mineral clay that is relatively inexpensive. It is effective as a support material. This behavior is governed by the extent and nature of the outer surface, the interspace, and the crystal structure that can be modified by appropriate processing techniques [13]. Acidic or alkaline activation has been widely studied as a chemical treatment to improve the characteristics of natural kaolinite. However, activation from natural kaolinite shows that improving the properties of kaolinite by chemical processes is difficult because of the high passivity of this material. Thus, it was not significantly affected by acidic or alkaline treatments, even under concentrated solution conditions [4-7].
Due to the passivity of kaolinite, acidic or alkaline activation was also studied from metakaolinite. It is a metastable phase obtained by calcination of kaolinite, which has been reported to be more reactive in chemical treatments. Metakaolinites are obtained by calcination of kaolinite at temperatures between 500 and $900{ }^{\circ} \mathrm{C}$ $[5,8]$. This transformation occurs by losing its structural water and a reorganization of the structure. Only a small part of $\mathrm{AlO}_{6}$ octahedron is maintained, while the rest is transformed into much more reactive tetra and pentacoordinate units. This process of dehydroxylation is presented in following equation [5].

$$
\begin{aligned}
\mathrm{Al}_{2} \mathrm{O}_{3}\left(\mathrm{SiO}_{2}\right)_{2}\left(\mathrm{H}_{2} \mathrm{O}\right)_{2} \text { (kaolinite) } \rightarrow & \mathrm{Al}_{2} \mathrm{O}_{3}\left(\mathrm{SiO}_{2}\right)_{2}\left(\mathrm{H}_{2} \mathrm{O}\right)_{\mathrm{x}} \\
& +(2-\mathrm{x}) \mathrm{H}_{2} \mathrm{O} \uparrow
\end{aligned}
$$


The calcination conditions of kaolinite strongly influence the reactivity of the solids obtained. The best conditions for obtaining a highly reactive metakaolinite were discussed by various authors who reported calcination values between 600 and $800{ }^{\circ} \mathrm{C}$ [5,9-10]. Calcination at higher temperatures leads to the formation of mullite and cristobalite. In this study, we used the calcination temperature of $600{ }^{\circ} \mathrm{C}$ according to the adapted protocol written by Belver et al. [5].

Rahmalia et al. [6] previously studied the characterization of $\mathrm{HCl}$ and $\mathrm{KOH}$ treated kaolinite and their adsorption properties against bixin (Fig. 1). The results showed that there was only little change in the kaolinite structure after treatment. However, the activation of kaolinite using alkaline solutions allowed the increase of the adsorption capacity of bixin, both isotherms adsorptions, and kinetics. Bixin was chosen in this study because it is a carotenoid dye that is widely used in industry, cosmetics, pharmaceutical products, as food coloring, textile dye [11-14], sensitizer in the solar cell [15-17] and photodynamic therapy [18]. The double bonds structure of bixin renders it unstable to light, temperature, and oxygen exposure [19-20]. Incorporating bixin into the surface or interlayer space of clay minerals is one of the efforts to increase its stability [21-22].

In line with the development of environmentally friendly technologies, $\mathrm{NH}_{4} \mathrm{OH}$ is a less toxic alternative to $\mathrm{KOH}$. KOH strongly attacks cell constituents by dissolving keratin, hydrolyzing lipids, and degrading proteins. The destructive effect of $\mathrm{KOH}$ on the eyes is particularly serious. The effect of $\mathrm{NH}_{4} \mathrm{OH}$ is less severe. The corrosive effects of $\mathrm{NH}_{4} \mathrm{OH}$ cause destruction of single tissues, while $\mathrm{KOH}$ causes severe tissue destruction [23]. $\mathrm{NH}_{4} \mathrm{OH}$ enters the nitrogen cycle. It is produced in the soil by bacterial methods. $\mathrm{NH}_{4} \mathrm{OH}$ is also produced naturally from the decomposition of organic matter [24]. So we used $\mathrm{NH}_{4} \mathrm{OH}$ in this work. Since the alkaline properties of $\mathrm{NH}_{4} \mathrm{OH}$ are almost the same as $\mathrm{KOH}$, it is advantageous to develop a new activator which has less toxicity, and is believed to also improve surface properties of natural kaolinite.

Although the bixin adsorption rate on kaolinite is faster when acetone acts as a solvent, it is preferred to use dimethyl carbonate (DMC) since it can increase the adsorptive capacity of bixin on kaolinite [6]. Most properties of DMC make it a truly green reagent [25]: (1) DMC is a non-toxic compound. Since the mid-1980s, it is no longer produced from phosgene, but rather by oxidative catalytic carbonylation of methanol with oxygen. In addition to improving the safety of the procedure, this manufacturing process avoids phosgene contamination and eliminates the need for inorganic salts as by-products. (2) DMC is classified as a flammable liquid just like methanol, and has no irritant or mutagenic effects, either by contact or by inhalation. Therefore, it can be handled safely without the special precautions required for toxic and mutagenic methyl halides. (3) DMC has a versatile and flexible chemical reactivity that depends on experimental conditions.

Thus, the objective of this work is the activation of metakaolinite using concentrated $\mathrm{NH}_{4} \mathrm{OH}$ solution to obtain the metakaolinite with better properties. The treatment of kaolinite using concentrated $\mathrm{NH}_{4} \mathrm{OH}$ was also done for comparative study. The parameters studied are the properties of kaolinite and metakaolinites after activation and its adsorption characteristics against bixin.

\section{EXPERIMENTAL SECTION}

\section{Materials}

Bixin crystals containing $88.11 \%$ cis-bixin and $11.75 \%$ di-cis-bixin and an unknown compound $(0.14 \%)$ were obtained by the extraction and purification processes described by Rahmalia et al. [26]. Natural kaolinite $\left(\mathrm{Al}_{2} \mathrm{O}_{7} \mathrm{Si}_{2} \cdot 2 \mathrm{H}_{2} \mathrm{O}\right)$, CAS Number 1318-74-7, was supplied by Sigma-Aldrich (Germany), together with analytical grade ammonium hydroxide $\left(\mathrm{NH}_{4} \mathrm{OH}, \mathrm{NH}_{3}\right.$ 28.0-30.0\%) and dimethyl carbonate (99\%) were supplied by Sigma-Aldrich, Germany.

\section{Procedure}

\section{Preparation and activation of metakaolinite by $\mathrm{NH}_{4} \mathrm{OH}$}

The kaolinite was calcined at $600^{\circ} \mathrm{C}$ in an oven to give the corresponding metakaolinite. The calcination was carried out under an air atmosphere in a programmable furnace, with a program for heating from 
room temperature to the calcination temperature by $10{ }^{\circ} \mathrm{C} \mathrm{min}^{-1}$ and maintaining the calcination temperature for $6 \mathrm{~h}$. The metakaolinite obtained was named $\mathrm{K}_{\text {Cal }}$. Activation was performed by adding $10 \mathrm{~g}$ of $\mathrm{K}_{\mathrm{Cal}}$ in $100 \mathrm{~mL}$ of a $5 \mathrm{M} \mathrm{NH}_{4} \mathrm{OH}$ solution. The mixture was stirred on a vibrating table continuously (300 rpm) for $6 \mathrm{~h}$ at room temperature. The suspension was filtered and the residue was washed using distilled water until neutral and dried in an oven at $103{ }^{\circ} \mathrm{C}$ for $24 \mathrm{~h}$. This process was repeated 3 times to optimize the activation process. The final product obtained was called $\mathrm{K}_{\mathrm{CA}}$. The activation of kaolinite without calcination was also done by a similar method, and the final product obtained was called $\mathrm{K}_{\mathrm{A}} \cdot \mathrm{K}_{\mathrm{A}}, \mathrm{K}_{\mathrm{Cal}}$, and $\mathrm{K}_{\mathrm{CA}}$ were characterized by XRD, FTIR, SEM-EDS, and BET-N.

\section{Adsorption of bixin on KB and KCA}

The adsorption process was carried out by adopting the experiment optimum condition of Rahmalia et al. [6]. Stock solutions of bixin $(20 \mathrm{mg} / \mathrm{L})$ were prepared in dimethyl carbonate. Solutions at the required concentrations $(3-18 \mathrm{mg} / \mathrm{L})$ were prepared by dilution of the stock solution. The adsorbent $(0.05 \mathrm{~g})$ was then added to a solution of $5 \mathrm{~mL}$ of bixin (3-18 $\mathrm{mg} / \mathrm{L})$. The mixtures were stirred on a vibrating table continuously (300 rpm) at room temperature $\left(\sim 22^{\circ} \mathrm{C}\right)$. Samples were taken after $4 \mathrm{~h}$ (predetermined equilibrium time) and small aliquots of the supernatant were removed and diluted to an appropriate concentration, if necessary. The absorption spectrum was determined immediately with a Shimadzu UV-1800 UV-visible spectrophotometer. Concentrations of bixin in the solutions were determined by a UV-visible spectrophotometer calibrated at $456 \mathrm{~nm}$ dimethyl carbonate [27]. For contact time studies, the residual concentration of $5 \mathrm{~mL}$ of bixin solution $(10 \mathrm{mg} / \mathrm{L})$ with kaolinite $(0.1 \mathrm{~g})$ was determined at various time points from 5 to $360 \mathrm{~min}$. The experiments were performed in triplicate and mean values were reported.

\section{- RESULTS AND DISCUSSION}

\section{Characteristics of Dealuminated Metakaolinite}

The XRD diffractograms (Fig. 1) show the amorphous patterns for $\mathrm{K}_{\mathrm{Cal}}$ and $\mathrm{K}_{\mathrm{CA}}$. The calcination process resulted in significant crystallographic transformations of kaolinite.

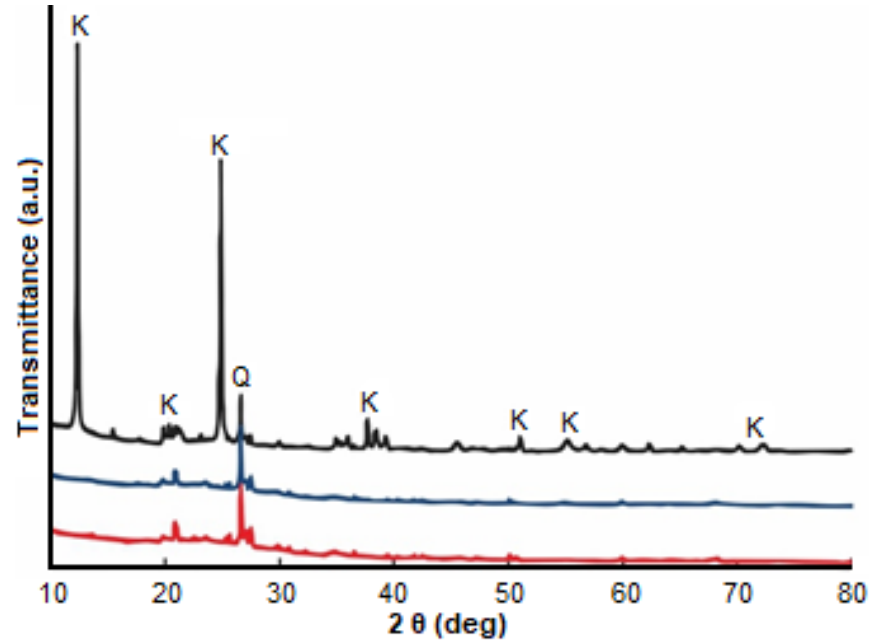

Fig 1. XRD diffragtograms of $K_{A}$ (black), $K_{\text {Cal }}$ (blue), and $\mathrm{K}_{\mathrm{CA}}$ (red)

Two intense diffraction reflections at $2 \theta$ values of 12.3 and $24.9^{\circ}$ which were observed at $\mathrm{K}_{\mathrm{A}}$ had disappeared, while peaks attributed to quartz ( $2 \theta$ of 21.22 and $27.45^{\circ}$ ) remained unchanged. A diffractogram for $\mathrm{K}_{\mathrm{A}}$ showed no significant difference with respect to kaolinite before activation as reported in Rahmalia et al. [6]. The calcination product patterns are similar to those reported for metakaolinites [5,9]. Since the activation of metakaolinite was performed at room temperature, the XRD pattern of $\mathrm{K}_{\mathrm{CA}}$ did not show significant variations from $\mathrm{K}_{\text {Call }}$. This indicates that treatment with $\mathrm{NH}_{4} \mathrm{OH}$ at room temperature leads to very small alterations in the crystal structure of metakaolinite. However, the International Centre for Diffraction Data (ICDD) shows that $\mathrm{K}_{\mathrm{CA}}$ (PDF 01-076-5970) contains a small amount of sodium aluminum silicon oxide. It is the precursor component of zeolite formation. This mineral is not present in the $\mathrm{K}_{\text {Call }}$. This result shows that $\mathrm{NH}_{4} \mathrm{OH}$ has the ability to convert metakaolinite to zeolite although activation was performed at room temperature.

FTIR analysis (Fig. 2) confirm the transformation of kaolinite during calcination and activation. The FTIR spectra patterns of $\mathrm{K}_{\mathrm{A}}$ showed no significant differences between kaolinite before and after treatment, indicating an absence of significant change in the kaolinite samples. The FTIR spectrum of natural kaolinite published by Rahmalia et al. [6] was also presented for comparison. The FTIR spectrum of natural kaolinite characteristic bands

Winda Rahmalia et al. 


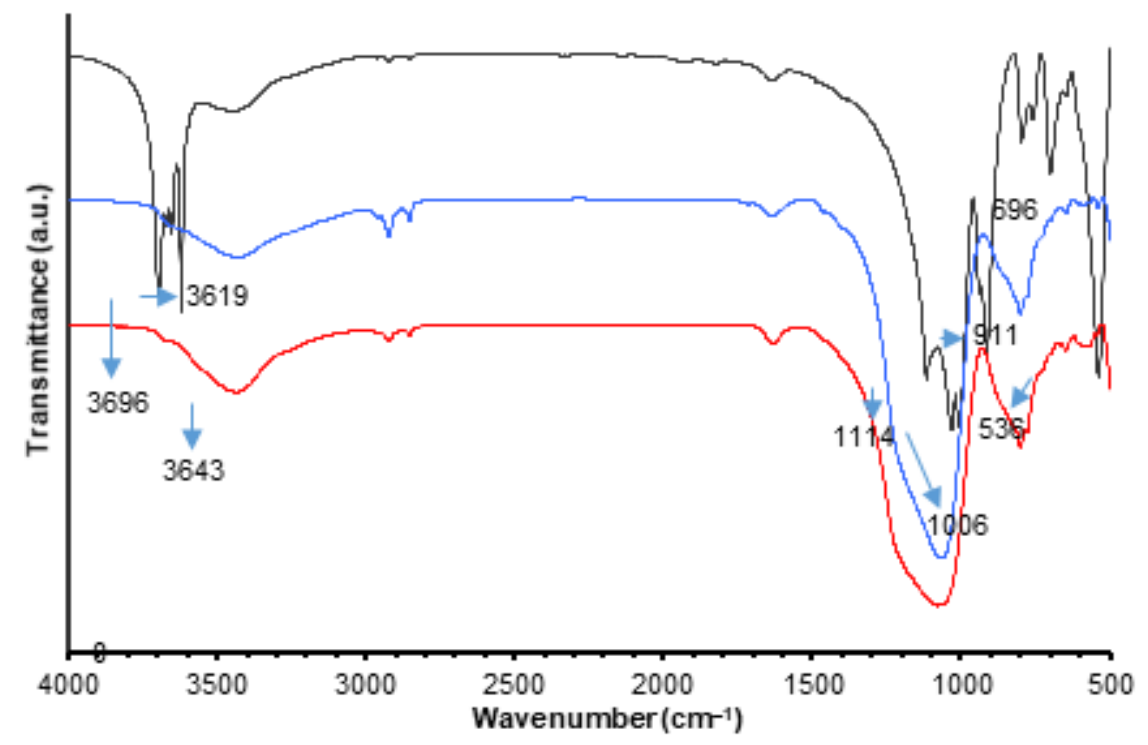

Fig 2. The FTIR spectra of $K_{A}$ (black), $K_{\text {Cal }}$ (blue), $K_{C A}$ (red)

of kaolinite: at 3696, 3669, 3652, and $3619 \mathrm{~cm}^{-1}$ correspond to the stretching of inner-surface-hydroxyl groups, at $3443 \mathrm{~cm}^{-1}$ corresponds to stretching of the hydroxyl group of water, $1631 \mathrm{~cm}^{-1}$ corresponds to the $\mathrm{O}-\mathrm{H}$ deformation of water, $1114 \mathrm{~cm}^{-1}$ corresponds to $\mathrm{Si}-\mathrm{O}$ stretching (longitudinal mode), 1030 , and $1006 \mathrm{~cm}^{-1}$ correspond to in-plane Si-O stretching, $937 \mathrm{~cm}^{-1}$ corresponds to the $-\mathrm{OH}$ deformation of inner-surface hydroxyl groups, $911 \mathrm{~cm}^{-1}$ corresponds to Al-OH deformation, $794 \mathrm{~cm}^{-1}$ corresponds to $\mathrm{Si}-\mathrm{O}$ vibration, 755 and $696 \mathrm{~cm}^{-1}$ correspond to $\mathrm{Si}-\mathrm{O}$ perpendicular vibrations, $536 \mathrm{~cm}^{-1}$ corresponds to $\mathrm{Al}-\mathrm{O}-\mathrm{Si}$ deformation, $468 \mathrm{~cm}^{-1}$ corresponds to $\mathrm{Si}-\mathrm{O}-\mathrm{Si}$ deformation, and $428 \mathrm{~cm}^{-1}$ corresponds to $\mathrm{Si}-\mathrm{O}$ deformation.

The calcination process of kaolinite caused the almost complete disappearance of the water and hydroxyl bands. The stretching of inner-surface-hydroxyl groups bands at $3696,3669,3652$ and $3619 \mathrm{~cm}^{-1}$, and the $-\mathrm{OH}$ deformation of inner-surface hydroxyl groups band at $937 \mathrm{~cm}^{-1}$ also disappeared. This proves that the dehydroxylation process occurred. The significant decrease in $\mathrm{Al}-\mathrm{OH}$ deformation band at $911 \mathrm{~cm}^{-1}$ and $\mathrm{Al}-\mathrm{O}-\mathrm{Si}$ deformations at $536 \mathrm{~cm}^{-1}$ indicates that the evolution of octahedral $\mathrm{Al}^{3+}$ coordination in the kaolinite structure towards coordination tetrahedral in metakaolinite was observed.

The spectrum of metakaolinite shows a very simple spectrum, consisting of three broad bands centered at 1079,777 , and $470 \mathrm{~cm}^{-1}$. The first corresponds to the vibrations of the tetrahedral sheet, clearly showing the deformation of this sheet during calcination. The second band corresponds to silica or free quartz, unaffected by calcination. Finally, the third band corresponds to the structural flexural vibrations. The simplification of this region also shows the structural deformation of kaolinite in metakaolinite.

Glukhovsky et al. [28] proposed a general mechanism for the alkaline activation of materials consisting mainly of silica and reactive alumina. The mechanism of the Glukhovsky model is composed of joint destruction-coagulation-condensation-crystallization reactions. The first step is a decomposition of the $\mathrm{Si}-\mathrm{O}-\mathrm{Si}$ and $\mathrm{Al}-\mathrm{O}-\mathrm{Si}$ covalent bonds, which occurs as the $\mathrm{pH}$ of the alkaline solution increases. These groups are therefore transformed into a colloidal phase. Then, an accumulation of destruction products occurs, which often interacts with each other to form a coagulated structure, which leads to the third phase, the generation of a condensed and crystallized structure. In another study, Steinerova [29] reported that metakaolinite in a strong alkaline medium allows hydrolysis of metakaolinite source components and their disintegration during which bridging oxygen (BOS) converses to non-bridging oxygen (NBOs) precursors release (BOS $\rightarrow \mathrm{NBOs}$ ), leading to a solution of the hydrated units of $\mathrm{SiO}_{4}$ and $\mathrm{AlO}_{4}$. As a consequence, we did not observe any significant 
differences between the IR spectra of $\mathrm{K}_{\mathrm{CA}}$ and $\mathrm{K}_{\mathrm{Cal}}$. On the other hand, the Al-O-Si deformation band at $536 \mathrm{~cm}^{-1}$ completely disappeared, followed by the decrease in intensity of the $\mathrm{Si}-\mathrm{O}-\mathrm{Si}$ band at $468 \mathrm{~cm}^{-1}$.

Alkaline attack on the structure of metakaolinite produces a release of silicate and aluminate species in solution, with 5 or $6 \mathrm{Al}$ coordinates converted into 4coordinations during dissolution. In this case, the release of $\mathrm{Al}$ may be faster than that of Si [30]. This can be explained by the decrease in the percentage of $\mathrm{Al}$ in metakaolinite after activation as observed by elemental analysis using SEM-EDS (Table 1). According to SEMEDS data, the activation of metakaolinite by $\mathrm{NH}_{4} \mathrm{OH}$ allowed the dealumination of metakaolinite. The increase in the $\mathrm{Si} / \mathrm{Al}$ ratio was almost twice as high as in natural kaolinite, $\mathrm{K}_{\mathrm{A}}$ and $\mathrm{K}_{\text {Cal. }}$.

Table 2 shows that monolayer volume, surface area, and total pore volume decreased during calcination due to particle aggregation when water molecules was removed from the structure. Meanwhile the average pore diameter showed an increase, indicating that the high temperature calcination process also allowed pore opening by minimizing organic contaminations of natural kaolinite. The specific surface area and the total pore volume increased significantly after treatment for $\mathrm{K}_{\mathrm{CA}}$ because of the reorganization of the $\mathrm{K}_{\mathrm{Cal}}$ structure. These results show that metakaolinite is more reactive under treatment compared to natural kaolinite. $\mathrm{NH}_{4} \mathrm{OH}$ is capable of activating kaolinite by increasing slightly the surface area and average pore diameter of $\mathrm{K}_{\mathrm{A}}$. $\mathrm{NH}_{4} \mathrm{OH}$ was capable of dealuminating metakaolinite by increasing the surface area by up to 16 times more than natural kaolinite. It is probably due to the ability of concentrated $\mathrm{NH}_{4} \mathrm{OH}$ to dissolve aluminic and silicic part of metakaolinite.

Due to the change in chemical composition, the mapping of the elements was conducted for natural kaolinite and $\mathrm{K}_{\mathrm{CA}}$ using SEM-EDS with a magnification of $2000 \times$ to know their distributions of chemical elements. The results of the analyses are shown in Fig. 3. It is found that the elements of $\mathrm{O}, \mathrm{N}, \mathrm{Mg}, \mathrm{Al}, \mathrm{Si}$, and $\mathrm{K}$ of natural kaolinite were homogenously distributed. After calcination followed by activation, a new phase was observed forming more pores. Activation by $\mathrm{NH}_{4} \mathrm{OH}$ lead to the formation of pore domains that were larger in the clusters site of chemical elements such as $\mathrm{O}, \mathrm{Si}$, and $\mathrm{Al}$. This figure also shows the change in the distribution of the chemical elements of $\mathrm{Na}, \mathrm{Mg}$, and $\mathrm{K}$ but less important.

\section{Adsorption of Bixin on Dealuminated Metakaolinite}

For the comparison study with respect to natural kaolinite, $\mathrm{HCl}$ treated kaolinite, and $\mathrm{KOH}$ treated kaolinite, that Rahmalia et al. [6] had studied previously, we carried out the adsorption of bixin on $\mathrm{K}_{\mathrm{A}}$ and $\mathrm{K}_{\mathrm{CA}}$

Table 1. SEM-EDS analysis data

\begin{tabular}{lcccc}
\hline \multirow{2}{*}{ Element } & \multicolumn{4}{c}{ wt.\% } \\
\cline { 2 - 5 } & Natural kaolinite [11] & $\mathrm{K}_{\mathrm{A}}$ & $\mathrm{K}_{\mathrm{Cal}}$ & $\mathrm{K}_{\mathrm{CA}}$ \\
\hline $\mathrm{O}$ & 56.9 & 58.0 & 53.3 & 56.0 \\
$\mathrm{Na}$ & 0.42 & 0.45 & 0.29 & 0.37 \\
$\mathrm{Mg}$ & 0.15 & 0.26 & 0.31 & 0.19 \\
$\mathrm{Al}$ & 18.4 & 18.2 & 19.8 & 13.7 \\
$\mathrm{Si}$ & 23.1 & 22.5 & 24.5 & 28.1 \\
$\mathrm{~K}$ & 0.79 & 0.38 & 0.72 & 0.83 \\
$\mathrm{Fe}$ & 0.22 & 0.22 & 0.22 & 0.23 \\
$\mathrm{Si} / \mathrm{Al}$ & 1.26 & 1.23 & 1.24 & 2.06 \\
\hline
\end{tabular}

Table 2. BET- $\mathrm{N}_{2}$ analysis data

\begin{tabular}{|c|c|c|c|c|c|}
\hline \multicolumn{2}{|l|}{ Kaolinites } & Natural kaolinite [11] & $\mathrm{K}_{\mathrm{A}}$ & $\mathrm{K}_{\mathrm{Cal}}$ & $\mathrm{K}_{\mathrm{CA}}$ \\
\hline \multicolumn{2}{|c|}{ Weight of sample (g) } & 0.21 & 0.22 & 0.21 & 0.19 \\
\hline \multicolumn{2}{|c|}{ Saturation vapor pressure $(\mathrm{kPa})$} & 99.22 & 99.78 & 97.18 & 97.14 \\
\hline & Volume of monolayer, $\mathrm{V}_{\mathrm{m}}\left(\mathrm{cm}^{3} \mathrm{STP} \mathrm{g}^{-1}\right)$ & 1.76 & 1.88 & 1.64 & 28.57 \\
\hline BET & Constant of energy, C (first layer) & 42.94 & 35.99 & 122.07 & 2877.50 \\
\hline Parameters & Surface area BET, $\mathrm{a}_{\mathrm{s}}$ BET $\left(\mathrm{m}^{2} \mathrm{~g}^{-1}\right)$ & 7.65 & 8.15 & 7.13 & 124.33 \\
\hline \multirow[t]{2}{*}{ Analysis } & Total pore volume, $\mathrm{p} / \mathrm{p}_{0}=0.99\left(10^{-2} \mathrm{~cm}^{3} \mathrm{~g}^{-1}\right)$ & 3.62 & 2.89 & 2.34 & 7.43 \\
\hline & Average pore diameter, $\mathrm{d}_{\mathrm{p}}(\mathrm{nm})$ & 8.20 & 14.17 & 13.16 & 2.39 \\
\hline
\end{tabular}

Winda Rahmalia et al. 

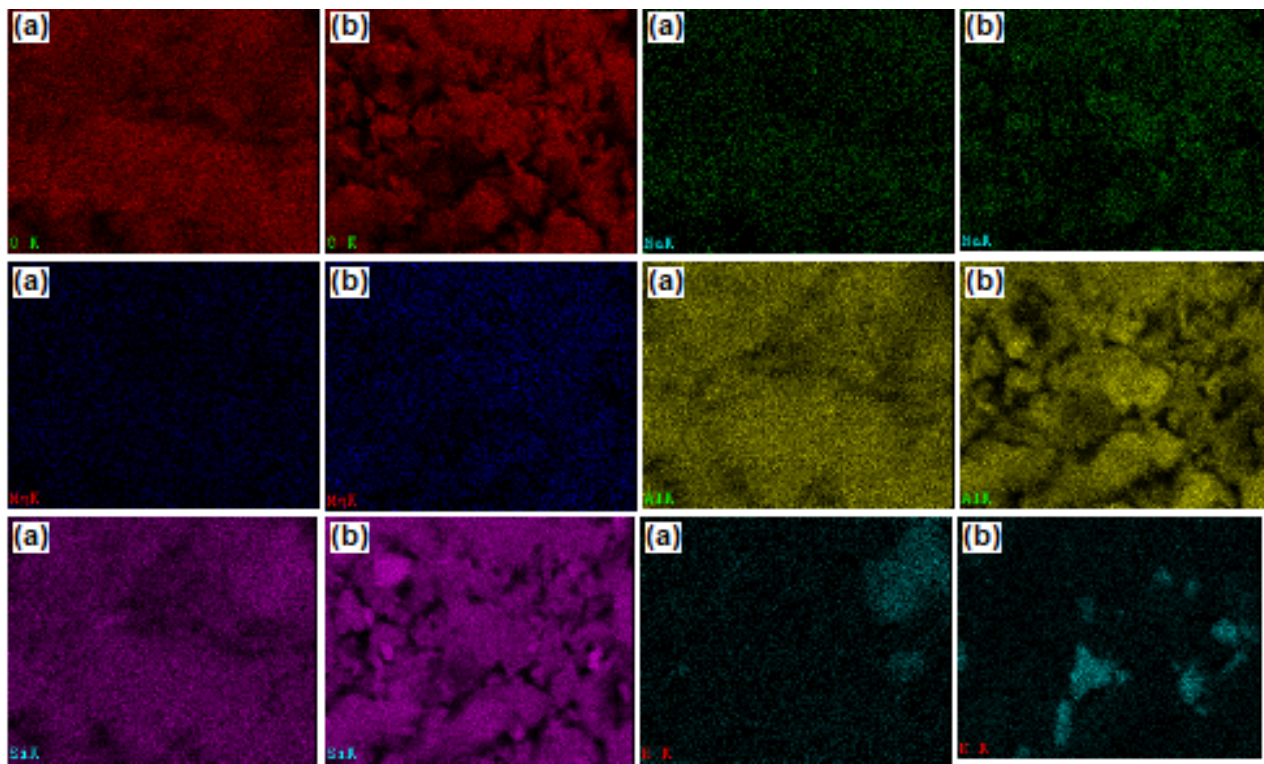

Fig 3. Cartography of elements of natural kaolinite (a) and $\mathrm{K}_{\mathrm{CA}}(\mathrm{b})$

using dimethyl carbonate as the solvent. The effect of contact time showed that bixin in dimethyl carbonate needed $240 \mathrm{~min}$ to wait for equilibrium (Fig. 4). The result was the same when natural kaolinite, $\mathrm{HCl}$ treated kaolinite, and $\mathrm{KOH}$ treated kaolinite were used as adsorbents.

The absorption spectrum of the supernatant solution of bixin in dimethyl carbonate before and after adsorption by $\mathrm{K}_{\mathrm{A}}$ and $\mathrm{K}_{\mathrm{CA}}$ for $240 \mathrm{~min}$ is shown in Fig. 5 . In contrast to the adsorption properties of bixin on natural kaolinite and treated kaolinite, the spectrum of bixin after adsorption on $\mathrm{K}_{\mathrm{CA}}$ showed a small red displacement (bathochromic). It appeared in the visible region and gave a maximum absorbance at $462 \mathrm{~nm}$, moving $6 \mathrm{~nm}$ with respect to the bixin spectrum before adsorption $(456 \mathrm{~nm})$, and is associated with the position of the $0-1$ band of vibrations. This behavior is an advantage in bixin applications as a photosensitizer. That is, less energy is needed for the bixin to be excited from HOMO to LUMO compared to bixin adsorbed on natural kaolinite and treated kaolinite.

In order to explain the design of an adsorption system and the interaction between bixin and metakaolinite in this study, we used the most common types of isotherms, which are the Langmuir and Freundlich models. They are the best models to explain the trend of adsorption based on the essence of absorbents saturated with adsorbate after

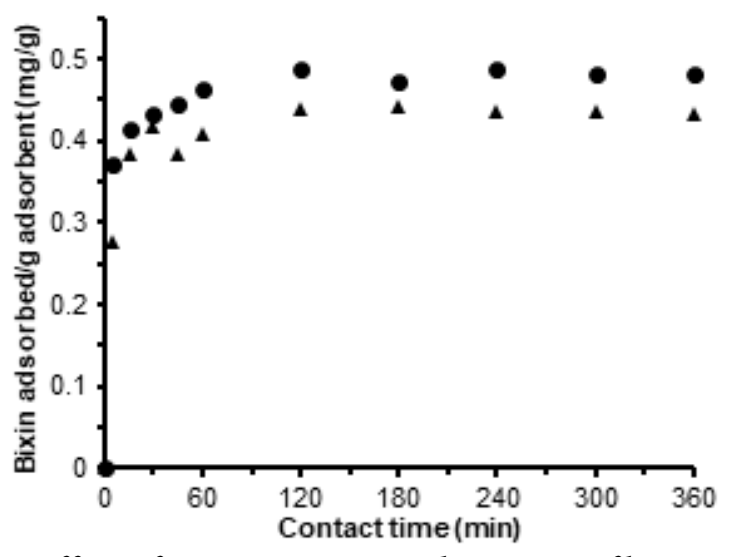

Fig 4. Effect of contact time on adsorption of bixin using $\mathrm{K}_{\mathrm{A}}(\mathbf{\Delta})$ and $\mathrm{K}_{\mathrm{CA}}(\bullet)$

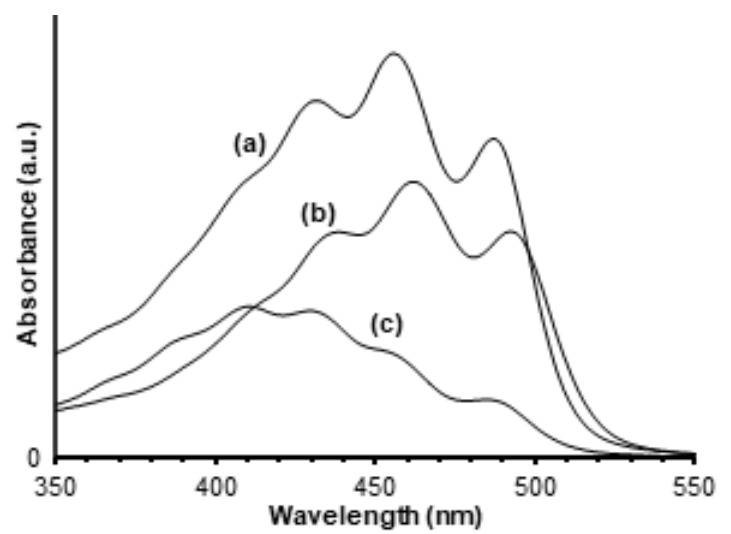

Fig 5. Supernatant solution absorption spectrum of bixin in dimethyl carbonate before (a) and after adsorption on $\mathrm{K}_{\mathrm{A}}(\mathrm{b})$ and $\mathrm{K}_{\mathrm{CA}}$ (c) 
enough contact time. Freundlich isotherm is applicable to adsorption processes that occur on heterogonous surfaces. This isotherm gives an expression which defines the surface heterogeneity and the exponential distribution of active sites and their energies. The linear form of the Freundlich isotherm is as follows [31]:

$\log \mathrm{q}_{\mathrm{e}}=\log \mathrm{K}_{\mathrm{f}}+\frac{1}{\mathrm{n}} \log \mathrm{C}_{\mathrm{e}}$

where $\mathrm{q}_{\mathrm{e}}$ is the amount of the adsorbate at equilibrium $(\mathrm{mg} / \mathrm{g}), \mathrm{C}_{e}$ is the equilibrium concentration of the adsorbate on the adsorbent $(\mathrm{mg} / \mathrm{L}), \mathrm{K}_{\mathrm{f}}$ is adsorption capacity $(\mathrm{L} / \mathrm{mg})$ and $1 / \mathrm{n}$ is adsorption intensity; it also indicates the relative distribution of the energy and the heterogeneity of the adsorbate sites.

In the Langmuir model, the mass of solute adsorbed per unit mass of adsorbent increases linearly with solute concentration at low surface coverage, approaching an asymptote as the adsorption sites become saturated. Eq. (2) is based on three important assumptions: (1) the energy of adsorption is identical for all sites and is independent of surface coverage, (2) adsorption occurs only at localized sites, with no interaction between adjoining adsorbed molecules, and (3) the sorption maximum represents monolayer coverage. The linear form of the Langmuir Eq. (2) can be expressed as follows [32]:
$\frac{\mathrm{C}_{\mathrm{e}}}{\mathrm{q}_{\mathrm{e}}}=\frac{1}{\mathrm{~K}_{\mathrm{L}} \cdot \mathrm{q}_{\mathrm{m}}}+\left(\frac{1}{\mathrm{q}_{\mathrm{m}}}\right) \mathrm{C}_{\mathrm{e}}$

where $\mathrm{K}_{\mathrm{L}}$ is Langmuir constant related to adsorption capacity $(\mathrm{mg} / \mathrm{g})$, which can be correlated with the variation of the suitable area and porosity of the adsorbent which implies that large surface area and pore volume will result in higher adsorption capacity, and $\mathrm{q}_{\mathrm{m}}$ is maximum adsorption capacity $(\mathrm{mg} / \mathrm{g})$.

Table 3 shows that the equilibrium data did not correspond to the Freundlich equation for $\mathrm{K}_{\mathrm{A}}$ and $\mathrm{K}_{\mathrm{CA}}$ in dimethyl carbonate. The poor fit of these models was demonstrated by the very low correlation coefficient $\left(\mathrm{r}^{2}\right.$ $<0.95)$ and the values of $n>1$. The Langmuir equation gave a better fit, with $r^{2}>0.95$. This indicates the presence of a homogeneous active site and the coverage of the adsorbent surface with a monolayer of bixin. Depending on the values of $\mathrm{q}_{\mathrm{m}}$, the bixin adsorption on $\mathrm{K}_{\mathrm{CA}}$ is favorable compared to $\mathrm{K}_{\mathrm{A}}$. This is predictable as the adsorption capacity of adsorbents increased with an increase in the specific surface area of BET.

The adsorption kinetics $\left(\mathrm{k}_{1}\right.$ and $\left.\mathrm{k}_{2}\right)$ were also calculated for $\mathrm{K}_{\mathrm{A}}$ and $\mathrm{K}_{\mathrm{CA}}$ as well as the correlation coefficient, the values of $\mathrm{q}_{\mathrm{e} 1}$ and $\mathrm{q}_{\mathrm{e} 2}$ (calculation) and $\mathrm{q}_{\mathrm{e}}$ (experiment) by using the Lagergren's pseudo-first order and pseudo-second order models to investigate the

Table 3. Adsorption parameters for the adsorption of bixin on $\mathrm{K}_{\mathrm{A}}$ and $\mathrm{K}_{\mathrm{AC}}$

\begin{tabular}{|c|c|c|c|}
\hline \multicolumn{2}{|c|}{ Adsorption isotherm parameters } & $\mathrm{K}_{\mathrm{A}}$ & $\mathrm{K}_{\mathrm{AC}}$ \\
\hline \multirow{3}{*}{ Freundlich } & $\mathrm{K}_{\mathrm{f}}(\mathrm{L} / \mathrm{mg})$ & 0.36 & 0.60 \\
\hline & $\mathrm{N}$ & 0.14 & 8.76 \\
\hline & $\mathrm{r}^{2}$ & 0.42 & 0.30 \\
\hline \multirow{3}{*}{ Langmuir } & $\mathrm{K}_{\mathrm{L}}(\mathrm{mg} / \mathrm{g})$ & 7.89 & 6.16 \\
\hline & $\mathrm{q}_{\mathrm{m}}(\mathrm{mg} / \mathrm{g})$ & 0.47 & 0.72 \\
\hline & $\mathrm{r}^{2}$ & 0.99 & 0.98 \\
\hline \multicolumn{2}{|c|}{ Adsorption kinetic parameters } & $\mathrm{K}_{\mathrm{A}}$ & $\mathrm{K}_{\mathrm{AC}}$ \\
\hline \multirow{4}{*}{ Pseudo-first order } & $\mathrm{q}_{\mathrm{e}} \exp (\mathrm{mg} / \mathrm{g})$ & 0.44 & 1.43 \\
\hline & $\mathrm{q}_{\mathrm{e} 1}(\mathrm{mg} / \mathrm{g})$ & 0.19 & 0.46 \\
\hline & $\mathrm{k}_{1}\left(10^{-2}\right)(1 / \mathrm{min})$ & 3.57 & 10.4 \\
\hline & $\mathrm{r}^{2}$ & 0.84 & 0.73 \\
\hline \multirow{4}{*}{ Pseudo-second order } & $\mathrm{q}_{\mathrm{e} 2}(\mathrm{mg} / \mathrm{g})$ & 0.44 & 1.41 \\
\hline & $\mathrm{h}\left(10^{-2}\right)(\mathrm{mg} / \mathrm{g} \mathrm{min})$ & 20.1 & 39.9 \\
\hline & $\mathrm{k}_{2}$ (mg/g.min) & 1.05 & 0.20 \\
\hline & $\mathrm{r}^{2}$ & 0.99 & 0.99 \\
\hline
\end{tabular}

Winda Rahmalia et al. 
dynamics of the bixin adsorption process. The pseudofirst order model assumes that the rate of change of solute uptake over time is directly proportional to the difference in saturation concentration and the amount of solid uptake over time. In most cases, the adsorption reaction involves diffusion across a boundary (3) [33]. The adsorption process with chemisorption controls the rate, according to the pseudo-second order model (4) [34].

$$
\begin{aligned}
& \log \left(\mathrm{q}_{\mathrm{e}}-\mathrm{q}_{\mathrm{t}}\right)=\log \mathrm{q}_{\mathrm{e}}-\mathrm{k}_{1} \cdot \frac{\mathrm{t}}{(2.303)^{\prime}} \\
& \frac{\mathrm{t}}{\mathrm{q}_{\mathrm{t}}}=\frac{1}{\left(\mathrm{k}_{2} \mathrm{q}_{\mathrm{e}}^{2}\right)}+\left(\frac{1}{\mathrm{q}_{\mathrm{m}}}\right) \cdot \mathrm{t}
\end{aligned}
$$

where $k_{1}$ is pseudo first order adsorption rate constant $(1 / \mathrm{min})$ and $\mathrm{k}_{2}$ is pseudo second order adsorption rate constant $(\mathrm{g} / \mathrm{mg} \mathrm{min})$. Values of $\mathrm{k}_{1}$ and $\mathrm{k}_{2}$ were calculated from the intercept of the corresponding plots of $\log \left(\mathrm{q}_{\mathrm{e}}-\right.$ $\mathrm{q}_{\mathrm{t}}$ ) against $\mathrm{t}$ and $\mathrm{t} / \mathrm{q}_{\mathrm{t}}$ against $\mathrm{t}$.

As seen in this table, the values of the correlation coefficients for the pseudo-second-order rate equation were found to be higher than those of the pseudo-firstorder rate equation. Although the $\mathrm{r}^{2}$ values for plots are in the range of 0.7329 after applying the pseudo-first order model, the calculated $\mathrm{q}_{\mathrm{el}}$ values obtained from this model do not give reasonable values because they are very small relative to the values of the experimental $\mathrm{q}_{\mathrm{e}}$. The values of $\mathrm{q}_{\mathrm{e} 2}$ and $\mathrm{q}_{\mathrm{e}}$ were close in agreement with the other values for the pseudo-second order model. These results confirm that the bixin adsorption process on both $\mathrm{K}_{\mathrm{A}}$ and $\mathrm{K}_{\mathrm{CA}}$ follow the pseudo-second-order kinetic model. These results prove that adsorption occurs in this experiment by chemisorption [35].

\section{- CONCLUSION}

The treatment of metakaolinite with $\mathrm{NH}_{4} \mathrm{OH}$ is a good method for producing the dealuminated metakaolinite with a very large surface area. The nature of the adsorption process depends on the physical and chemical characteristics of the adsorbents, as well as on the conditions of the system. The product obtained can also slightly decrease the energy required to excite the electrons of the bixin from HOMO to LUMO. It can also increase the capacity of kaolinite to adsorb bixin to almost twice the amount of activated kaolinites without an initial calcination phase. Finally, dimethyl carbonate has potential to be a good solvent for increasing the adsorptive capacity of bixin on kaolinite.

\section{- ACKNOWLEDGMENTS}

This study received financial support from the Ministry of Research Technology and the Higher Education Republic of Indonesia (KEMENRISTEK DIKTI) through the National Competitive Research (217/SP2H/LT/DRPM/2019) and Tanjungpura University through DIPA research (1945/UN22.8/KP/2018). We thank Cedric Charvillat (Centre Inter-universitaire de Recherche et d'Ingénierie des Matériaux), Gwénaëlle Raimbeaux (Laboratoire de Genie Chimique), and Deni Ferdian (Universitas Indonesia) for assistance with the analysis of kaolinite samples, by XRD, BET- $\mathrm{N}_{2}$, and EDS, respectively.

\section{- REFERENCES}

[1] Frost, R.L., Makó, É., Kristóf, J., and Kloprogge, J.T., 2002, Modification of kaolinite surface through mechanochemical treatment-a mid-IR and near-IR spectroscopic study, Spectrochim. Acta, Part A, 58 (13), 2849-2859.

[2] Frost, R.L., Kristóf, J., Makó, É., and Horváth, E., 2003, A DRIFT spectroscopic study of potassium acetate intercalated mechanochemically activated kaolinite, Spectrochim. Acta, Part A, 59, 1183-1194.

[3] Khan, T.A., Khan, E.A., and Shahjahan, 2015, Removal of basic dyes from aqueous solution by adsorption onto binary iron-manganese oxide coated kaolinite: Nonlinear isotherm and kinetics modeling, Appl. Clay Sci., 107, 70-77.

[4] Kumar, S., Panda, A.K., and Singh, R.K., 2013, Preparation and characterization of acid and alkaline treated kaolin clay, Bull. Chem. React. Eng. Catal., 8 (1), 61-69.

[5] Belver, C., Bañares-Muñoz, M.A., and Vicente, M.A., 2002, Chemical activation of kaolinite under acid and alkaline conditions, Chem. Mater., 14 (5), 2033-2043.

[6] Rahmalia, W., Fabre, J.F., Usman, T., and Mouloungui, Z., 2018, Adsorption characteristics of 
bixin on acid- and alkali-treated kaolinite in aprotic solvents, Bioinorg. Chem. Appl., 2018, 3805654.

[7] Yahaya, S., Jikan, S.S., Badarulzaman, N.A., and Adamu, A.D., 2017, Effect of acid treatment on the SEM-EDX characteristics of kaolin clay, Path Sci., 3 (9), 4001-4005.

[8] Mackenzie, R.C., 1970, Differential Thermal Analysis, Vol. I, Academic Press, London.

[9] Ilić, B.R., Mitrović, A.A., and Miličić, L.R., 2010, Thermal treatment of kaolin clay to obtain metakaolin, Hem. Ind., 64 (4), 351-356.

[10] Varga, G., 2007, The structure of kaolinite and metakaolinite, Epitöanyag, 59, 6-9.

[11] Cardarelli, C.R., Benassi, M.T., and Mercadante, A.Z., 2008, Characterization of different annatto extracts based on antioxidant and colour properties, LWT Food Sci. Technol., 41 (9), 1689-1693.

[12] Das, D., Maulik, S.R., and Bhattacharya, S.C., 2007, Dyeing of wool and silk with Bixa orellana, Indian J. Fibre Text. Res., 32 (3), 366-372.

[13] dos Santos, G.C., Mendonça, L.M., Antonucci, G.A., dos Santos, A.C., Antunes, L.M.G.A., and Bianchi, M.L.P., 2012, Protective effect of bixin on cisplatininduced genotoxicity in PC12 cells, Food Chem. Toxicol., 50 (2), 335-340.

[14] Venugopalan, A., Giridhar, P., and Ravishankar, G.A., 2011, Food, ethanobotanical and diversified applications of Bixa orellana L.: A scope for its improvement through biotechnological mediation, Indian J. Fundam. Appl. Life Sci., 1 (4), 9-31.

[15] Gómez-Ortíz, N.M., Vázquez-Maldonado, I.A., Pérez-Espadas, A.R., Mena-Rejón, G.J., AzamarBarrios, J.A., and Oskam, G., 2010, Dye-sensitized solar cells with natural dyes extracted from achiote seeds, Sol. Energy Mater. Sol. Cells, 94 (1), 40-44.

[16] Hiendro, A., Hadari, F., Rahmalia, W., and Wahyuni, N., 2012, Enhanced performance of bixin-sensitized $\mathrm{TiO}_{2}$ solar cells with activated kaolinite, IJERI, 4 (1), 40-44.

[17] Ruiz-Anchondo, T., Flores-Holguín, N., and Glossman-Mitnik, D., 2010, Natural carotenoids as nanomaterial precursors for molecular photovoltaics: A computational DFT study, Molecules, 15 (7), 4490-4510.

[18] Olson, M., and Allen, N.D., 2012, Natural photodynamic agents and their use, Patent, EP2214495A4.

[19] Montenegro, M.A., Rios, A.O., Mercadante, A.Z., Nazareno, M.A., and Borsarelli, C.D., 2004, Model studies on the photosensitized isomerization of bixin, J. Agric. Food Chem., 52 (2), 367-373.

[20] Rios, A.O., Borsarelli, C.D., and Mercadante, A.Z., 2005, Thermal degradation kinetics of bixin in an aqueous model system, J. Agric. Food Chem., 53 (6), 2307-2311.

[21] Kohno, Y., Inagawa, M., Ikoma, S., Shibata, M., Matsushima, R., Fukuhara, C., Tomita, Y., Maeda, Y., and Kobayashi, K., 2011, Stabilization of a hydrophobic natural dye by intercalation into organo-montmorillonite, Appl. Clay Sci., 54 (3-4), 202-205.

[22] Rahmalia, W., 2009, Synthesis of kaolinite-bixin organoclay and their photostability test, Thesis, Magister of Biology, Christian University of Satya Wacana, Salatiga, Indonesia.

[23] Picot, P.A., and Grenouillet, P., 1995, Safety in the Chemistry and Biochemistry Laboratory, Eds. Prokopetz, A.T., and Walters, D.B., Wiley-VCH, Inc., New York.

[24] Portejoie, S., Martinez, J., and Landmann, G., 2002, L'ammoniac d'origine agricole: Impacts sur la santé humaine et animale et sur le milieu naturel, INRA Prod. Anim., 15 (3), 151-160.

[25] Tundo, P., and Selva, M., 2002, The chemistry of dimethyl carbonate, Acc. Chem. Res., 35 (9), 706716.

[26] Rahmalia, W., Fabre, J.F., and Mouloungui, Z., 2015, Effect of cyclohexane/acetone ratio on bixin extraction yield by accelerated solvent extraction method, Procedia Chem., 14, 455-464.

[27] Rahmalia, W., Fabre, J.F., Usman, T., and Mouloungui, Z., 2014, Aprotic solvents effect on the UV-visible absorption spectra of bixin, Spectrochim. Acta, Part A, 131, 455-460. 
[28] Glukhovsky, V.D., Rostovskaja, G.S., and Rumyna, G.V., 1980, High strength slag alkaline cement, Proceedings of the $7^{\text {th }}$ International Congress on the Chemistry of Cement, Paris, 3, 164-168.

[29] Steinerova, M., 2010, Microporous inorganic polymers based on metakaolinite and their open porosity structure of $10-20 \mathrm{~nm}$ in diameter, The $2^{\text {nd }}$ International Conference NANOCON 2010, Olomouc, Czech Republic, 12-14 October 2010.

[30] Li, C., Sun, H., and Li, L., 2010, A review: The comparison between alkali-activated slag $(\mathrm{Si}+\mathrm{Ca})$ and metakaolin $(\mathrm{Si}+\mathrm{Al})$ cement, Cem. Concr. Res., 40 (9), 1341-1349.

[31] Freundlich, H., 1906, Adsorption in solution, $Z$.
Phys. Chem., 57, 385-470.

[32] Langmuir, I, 1916, The constitution and fundamental properties of solids and liquids, Part I. Solids, J. Am. Chem. Soc., 38 (11), 2221-2295.

[33] Lagergren, S., 1898, About the theory of so-called adsorption of soluble substances, Kungl. Svenska Vetenskapsakad. Handl., 24 (4), 1-39.

[34] Ho, Y.S., and McKay, G., 1999, Pseudo-second order model for sorption processes, Process Biochem., 34 (5), 451-465.

[35] Vimonses, V., Lei, S., Jin, B., Chow, C.W.K., and Saint, C., 2009, Adsorption of congo red by three Australian kaolins, Appl. Clay Sci., 43 (3-4), 465472. 